\title{
1-(Arylmethyloxy)anthracenes: how substituents affect their photoreactivity and ability to initiate radical and cationic polymerizations
}

\author{
Taka-aki Kageyama, Yuhta Koizumi, Tetsutaro Igarashi and Tadamitsu Sakurai \\ This study sought to aid in the development of an efficient, novel hybrid photoinitiator by examining the bond cleavage \\ of 1-(arylmethyloxy)anthracenes 1 performing as a bichromophoric photoinitiator in the polymerization of styrene (St) and \\ cyclohexene oxide (CHO) and classifying the cleavage as heterolytic or homolytic. The results indicated that the bichromophoric \\ photoinitiator 1, containing no halogen or metal, induces radical and cationic polymerization reactions of St and $\mathrm{CHO}$, \\ respectively, to generate high yields of the corresponding polymers. In addition, an analysis of the effects of substituents on \\ the photoreactivity and polymer yield of 1 indicated that the ability of the resultant radical or ion pair intermediate that was \\ generated by the photolysis of 1 to initiate polymerization increased with the enhanced stability of the reactive intermediate. \\ An analysis of the polymer end groups and photoproducts that were derived from specific initiators demonstrated that the \\ arylmethyloxyl radical and arylmethyl carbocation are the reactive species involved in the initiation steps of the polymerization \\ reactions for St and $\mathrm{CHO}$, respectively.
}

Polymer Journal (2012) 44, 1022-1029; doi:10.1038/pj.2012.57; published online 18 April 2012

Keywords: cationic polymerization; initiator; photochemistry; radical polymerization; substituent effect

\section{INTRODUCTION}

Various types of functional initiators have been developed for use in photochemistry. ${ }^{1}$ Much of the recent research has focused on novel photoinitiators that promote the initiation of both radical and cationic polymerizations, ${ }^{2-8}$ because a combination of these two polymerizations could produce a hybrid polymer that is composed of radical- and cation-derived polymer units. For example, interpenetrating network polymers ${ }^{9-11}$ combine the properties of these two polymer units and represent an attractive research area with many practical applications.

Although some salt-type photoinitiators can initiate both cationic and radical polymerizations, ${ }^{2-5,8,12,13}$ they have limited industrial application because they have low monomer solubility and require metal- or halogen-containing inorganic initiators. To overcome these limitations, nonsalt photoinitiators have been developed. Unfortunately, these photoinitiators are limited in their ability to induce hybrid polymerization. ${ }^{67,14}$ A systematic study of the photoreactivity of $O$-substituted anthracene-9-methanol derivatives in methanol revealed that in the singlet excited state, an intramolecular charge-transfer interaction assisted in the heterolytic $\mathrm{CH}_{2}-\mathrm{O}$ bond cleavage to generate ion and radical pairs. ${ }^{15}$ Therefore, these derivatives are good candidates for a novel hybrid-type photoinitiator that does not require halogen or metal. Although $\mathrm{O}$-acyl anthracene-9-methanol functioned as a photoinitiator for the radical polymerization of styrene $(\mathrm{St})$, it induced the cationic polymerization of cyclohexene oxide $(\mathrm{CHO})$ to only a minor extent. ${ }^{14}$ This finding suggests that the significantly lower polarity of $\mathrm{CHO}$ compared with methanol results in inefficient heterolytic bond cleavage in the singlet excited state.

We began to develop a hybrid-type photoinitiator that was capable of efficiently inducing heterolysis in $\mathrm{CHO}$. As the dramatically increased acidity of naphthol in the singlet excited state would be expected to significantly accelerate the heterolytic $\mathrm{CH}_{2}-\mathrm{O}$ bond cleavage reaction, ${ }^{16}$ 2-arylmethyloxy-6-cyanonaphthalenes were synthesized as prospective photoinitiators. An analysis of the product distribution obtained by the photolysis of these cyanonaphthalene derivatives in toluene and 1,2-dimethoxyethane revealed that in 1,2-dimethoxyethane, the cyanonaphthalene initiator undergoes both heterolytic and homolytic bond cleavage reactions, whereas in toluene, only the latter occurs. ${ }^{17}$ There was a decreased ability to initiate cationic photopolymerization of $\mathrm{CHO}$, thus owing to the weak absorption of the cyano-substituted naphthol chromophore at wavelengths greater than $320 \mathrm{~nm} .{ }^{17}$ Considering the strong absorption of the anthracene chromophore at these wavelengths, ${ }^{7,15}$ we designed the 1-arylmethyloxyanthracene photoinitiator $\mathbf{1}$ shown in Figure 1. Furthermore, to develop an efficient hybrid photoinitiator, we closely examined the effect that structural changes have on the ability of the initiator-derived reactive 
<smiles>[R7]c1cc([R7])c2ccccc2c1COc1cccc2cc3ccccc3cc12</smiles><smiles>COc1c(COc2cccc3cc4ccccc4cc23)ccc2ccccc12</smiles>

1a $\left(R^{1}=R^{2}=H\right)$;

$1 e$

1b $\left(R^{1}=M e, R^{2}=H\right)$;

$1 c\left(R^{1}=O M e, R^{2}=H\right)$;

1d $\left(R^{1}=H, R^{2}=O M e\right)$

Figure 1 Structures of $\mathbf{1 a - g}$.

species to initiate polymerization. To accomplish this, we examined the effect of an arylmethyl group on the photoreactivity of newly designed photoinitiators 1a-f (Figure 1) and the yield of poly(styrene) (PSt) and poly(cyclohexene oxide) (PCHO).

Photochemical solvolysis of $m$-methoxybenzyl acetate resulted in the formation of heterolytic $\mathrm{C}-\mathrm{O}$ bond cleavage products and homolytic products. Conversely, the solvolysis of $p$-methoxybenzyl acetate resulted in only homolytic products. ${ }^{18}$ This novel substituent effect on the type of $\mathrm{C}-\mathrm{O}$ bond cleavage was termed the 'meta effect' when it was introduced by Zimmerman and coworker. ${ }^{18-20}$ Although some controversy still exists about the mechanisms responsible for this type of $\mathrm{C}-\mathrm{O}$ bond cleavage, ${ }^{19-25}$ the use of 3,5-dimethoxybenzyl as an arylmethyl group (1g) to enhance the initiation of polymerization by $\mathbf{1}$ is an interesting extension of the substituent effect (Figure 1). In this paper, we present results demonstrating that 1-(2-methoxynaphthalen-1-ylmethyloxy)anthracene (1c) is a strong candidate for use as a hybrid photoinitiator consisting of only carbon, hydrogen and oxygen atoms.

\section{EXPERIMENTAL PROCEDURE}

\section{Materials}

The compound 1-hydroxyanthracene was prepared by treating an aqueous ethanol solution of 1-aminoanthracene with a saturated $\mathrm{NaHSO}_{3}$ solution for $20 \mathrm{~h}$ at $70^{\circ} \mathrm{C}$. The resultant compound was then treated with a $6-\mathrm{mol} \mathrm{dm}^{-3}$ $\mathrm{KOH}$ solution and concentrated hydrochloric acid. 1-(Methoxy-substituted arylmethyloxy)anthracene derivatives $(\mathbf{1} \mathbf{a}-\mathbf{g})$ were prepared according to the following procedure. After sodium hydride (60\% purity) was slowly added to a N,N-dimethylformamide solution of 1-hydroxyanthracene with stirring, 1-(chloromethyl)naphthalene, 1-chloromethyl-2-methylnaphthalene, 1-chloromethyl-2-methoxynaphthalene, 1-chloromethyl-4-methoxynaphthalene, 2-chloromethyl-1-methoxynaphthalene, 2-chloromethyl-3-methoxynaphthalene or 3,5-dimethoxybenzyl chloride was allowed to react with the hydroxyanthracene-derived sodium salt for $3 \mathrm{~h}$ at room temperature. After $3 \mathrm{~h}$, the reaction mixture was poured into ice-chilled water and the crystalline solid that precipitated was extracted with ethyl acetate. The ethyl acetate solution was washed several times with water and dried over anhydrous $\mathrm{MgSO}_{4}$. The residual solid obtained by removing the solvent under reduced pressure was recrystallized from ethyl acetate to provide analytical grade products $\mathbf{1 a}-\mathbf{g}$ at a $42-60 \%$ yield. The physical and spectroscopic data for 1-hydroxyanthracene (obtained at a $65 \%$ yield) and $\mathbf{1 a}-\mathbf{g}$ are as follows:

1-Hydroxyanthracene, mp 143.5-144.0 ${ }^{\circ} \mathrm{C}$; IR $\left(\mathrm{KBr}, \mathrm{cm}^{-1}\right)$ : 3237; ${ }^{1} \mathrm{H}$ NMR $\left(500 \mathrm{MHz}, \mathrm{CDCl}_{3}\right): \delta 5.46(1 \mathrm{H}, \mathrm{s}), 6.77(1 \mathrm{H}, \mathrm{d}, J=6.9 \mathrm{~Hz}), 7.29(1 \mathrm{H}, \mathrm{dd}$, $J=6.9,8.6 \mathrm{~Hz}), 7.45-7.49(2 \mathrm{H}, \mathrm{m}), 7.61(1 \mathrm{H}, \mathrm{d}, J=8.6 \mathrm{~Hz}), 7.99(1 \mathrm{H}, \mathrm{d}$, $J=6.9 \mathrm{~Hz}), 8.05(1 \mathrm{H}, \mathrm{d}, J=6.9 \mathrm{~Hz}), 8.39(1 \mathrm{H}, \mathrm{s}), 8.77(1 \mathrm{H}, \mathrm{s}) ;{ }^{13} \mathrm{C} \mathrm{NMR}$ $\left(125 \mathrm{MHz}, \mathrm{CDCl}_{3}\right): \delta 106.3,120.6,125.1,125.3,125.7$ (2C), 125.9, 128.0, 128.7 (2C), 131.2, 132.0, 132.8, 151.4.<smiles>COc1cc(COc2cccc3cc4ccccc4cc23)cc(OC)c1</smiles>

1-(1-Naphthylmethyloxy)anthracene (1a), mp $129.0-130.0^{\circ} \mathrm{C}$; IR $\left(\mathrm{KBr}, \mathrm{cm}^{-1}\right)$ : ${ }^{1} 260 ;{ }^{1} \mathrm{H}$ NMR $\left(500 \mathrm{MHz}, \mathrm{CDCl}_{3}\right): \delta 5.75(2 \mathrm{H}, \mathrm{s}), 6.98(1 \mathrm{H}, \mathrm{d}, J=7.5 \mathrm{~Hz})$, $7.25-7.45(3 \mathrm{H}, \mathrm{m}), 7.53-7.56(3 \mathrm{H}, \mathrm{m}), 7.64(1 \mathrm{H}, \mathrm{d}, J=8.5 \mathrm{~Hz}), 7.76(1 \mathrm{H}, \mathrm{d}$, $J=6.9 \mathrm{~Hz}), 7.92-7.98(4 \mathrm{H}, \mathrm{m}), 8.18(1 \mathrm{H}, \mathrm{d}, J=6.9 \mathrm{~Hz}), 8.39(1 \mathrm{H}, \mathrm{s}), 8.82(1 \mathrm{H}$, s); $\left.{ }^{13} \mathrm{C} \mathrm{NMR} \mathrm{(125} \mathrm{MHz,} \mathrm{CDCl}_{3}\right): \delta 68.9,103.0,120.9,121.3,123.9,125.1$ (2C), $125.2,125.4,125.7$ (2C), 126.0, 126.5, 126.7, 127.8, 128.7, 128.8, 129.1, 131.2, 131.8, 132.0, 132.4, 132.7, 133.8, 154.7. (Found: C, 89.89; H, 5.77\%. Calculated for $\mathrm{C}_{25} \mathrm{H}_{18} \mathrm{O}$ : C, 89.79; $\left.\mathrm{H}, 5.43 \%\right)$.

1-(2-Methylnaphthalen-1-ylmethyloxy)anthracene (1b), mp $180.5-181.5^{\circ} \mathrm{C}$; IR $\left(\mathrm{KBr}, \mathrm{cm}^{-1}\right): 1257 ;{ }^{1} \mathrm{H}$ NMR $\left(500 \mathrm{MHz}, \mathrm{CDCl}_{3}\right): \delta 2.70(3 \mathrm{H}, \mathrm{s}), 5.71(2 \mathrm{H}$, s), $7.08(1 \mathrm{H}, \mathrm{d}, J=7.4 \mathrm{~Hz}), 7.36(1 \mathrm{H}, \mathrm{d}, J=7.4 \mathrm{~Hz}), 7.40-7.48(5 \mathrm{H}, \mathrm{m}), 7.66$ $(1 \mathrm{H}, \mathrm{d}, J=8.5 \mathrm{~Hz}), 7.84-7.96(4 \mathrm{H}, \mathrm{m}), 8.15(1 \mathrm{H}, \mathrm{d}, J=6.3 \mathrm{~Hz}), 8.38(1 \mathrm{H}, \mathrm{s})$, $8.68(1 \mathrm{H}, \mathrm{s}) ;{ }^{13} \mathrm{C}$ NMR $\left(125 \mathrm{MHz}, \mathrm{CDCl}_{3}\right): \delta 20.0,64.0,102.6,120.8,121.4$, $123.8,125.0(2 \mathrm{C}), 125.1,125.3,125.5,125.6,126.7$ (2C), 127.8, 128.4, 128.8, 129.1, 129.2, 131.2, 132.0, 132.5, 132.7, 133.2, 136.1, 155.2. (Found: C, 89.29; $\mathrm{H}, 5.88 \%$. Calculated for $\left.\mathrm{C}_{26} \mathrm{H}_{20} \mathrm{O}: \mathrm{C}, 89.62 ; \mathrm{H}, 5.79 \%\right)$.

1-(2-Methoxynaphthalen-1-ylmethyloxy)anthracene (1c), mp 144.0-145.0 ${ }^{\circ} \mathrm{C}$; IR $\left(\mathrm{KBr}, \mathrm{cm}^{-1}\right): 1257 ;{ }^{1} \mathrm{H}$ NMR $\left(500 \mathrm{MHz}, \mathrm{CDCl}_{3}\right): \delta 4.02(3 \mathrm{H}, \mathrm{s}), 5.80(2 \mathrm{H}, \mathrm{s})$, $7.11(1 \mathrm{H}, \mathrm{d}, J=7.4 \mathrm{~Hz}), 7.35-7.47(6 \mathrm{H}, \mathrm{m}), 7.62(1 \mathrm{H}, \mathrm{d}, J=8.6 \mathrm{z}), 7.86(1 \mathrm{H}, \mathrm{d}$, $J=8.0 \mathrm{~Hz}), 7.87(1 \mathrm{H}, \mathrm{d}, J=8.0 \mathrm{~Hz}), 7.95(1 \mathrm{H}, \mathrm{d}, J=8.0 \mathrm{~Hz}), 7.97(1 \mathrm{H}, \mathrm{d}$, $J=8.0 \mathrm{~Hz}), 8.16(1 \mathrm{H}, \mathrm{d}, J=8.6 \mathrm{~Hz}), 8.36(1 \mathrm{H}, \mathrm{s}), 8.72(1 \mathrm{H}, \mathrm{s}) ;{ }^{13} \mathrm{C} \mathrm{NMR}$ $\left(125 \mathrm{MHz}, \mathrm{CDCl}_{3}\right): \delta 56.9,61.2,102.9,113.4,117.2,120.5,121.5,123.8,123.9$, $124.9,125.3,125.4$ (2C), 125.5, 127.1, 127.8, 128.3, 128.8, 129.2, 130.9, 131.1, $131.9,132.7,134.1,155.1,155.7$. (Found: C, $85.90 ; \mathrm{H}, 5.51 \%$. Calculated for $\left.\mathrm{C}_{26} \mathrm{H}_{20} \mathrm{O}_{2}: \mathrm{C}, 85.69 ; \mathrm{H}, 5.53 \%\right)$.

1-(4-Methoxynaphthalen-1-ylmethyloxy)anthracene (1d), mp $154.0-155.5^{\circ} \mathrm{C}$; IR $\left(\mathrm{KBr}, \mathrm{cm}^{-1}\right): 1261 ;{ }^{1} \mathrm{H}$ NMR $\left(500 \mathrm{MHz}, \mathrm{CDCl}_{3}\right): \delta 06(3 \mathrm{H}, \mathrm{s}), 5.64(2 \mathrm{H}, \mathrm{s})$, $6.86(1 \mathrm{H}, \mathrm{d}, J=8.0 \mathrm{~Hz}), 6.99(1 \mathrm{H}, \mathrm{d}, J=7.4 \mathrm{~Hz}), 7.38-7.54(6 \mathrm{H}, \mathrm{m}), 7.63(1 \mathrm{H}$, d, $J=7.4 \mathrm{~Hz}), 7.63(1 \mathrm{H}, \mathrm{d}, J=7.4 \mathrm{~Hz}), 7.91(1 \mathrm{H}, \mathrm{d}, J=8.6 \mathrm{~Hz}), 7.97(1 \mathrm{H}, \mathrm{d}$, $J=8.6 \mathrm{~Hz}), 8.13(1 \mathrm{H}, \mathrm{d}, J=8.0 \mathrm{~Hz}), 8.38(1 \mathrm{H}, \mathrm{s}), 8.78(1 \mathrm{H}, \mathrm{s}) ;{ }^{13} \mathrm{C} \mathrm{NMR}$ $\left(125 \mathrm{MHz}, \mathrm{CDCl}_{3}\right): \delta 55.6,69.1,102.9,103.0,120.7,121.4,122.6,123.9,124.5$, $125.0,125.2,125.3$ (2C) $125.4,125.6,126.0,127.1,127.7,127.8,128.8,131.2$, 131.9, 132.7, 133.0, 154.8, 156.2. (Found: C, 85.35; H, 5.44\%. Calculated for $\left.\mathrm{C}_{26} \mathrm{H}_{20} \mathrm{O}_{2}: \mathrm{C}, 85.69 ; \mathrm{H}, 5.53 \%\right)$.

1-(1-Methoxynaphthalen-2-ylmethyloxy)anthracene (1e), mp 118.0-119.5 ${ }^{\circ} \mathrm{C}$; IR $\left(\mathrm{KBr}, \mathrm{cm}^{-1}\right): 1265 ;{ }^{1} \mathrm{H}$ NMR $\left(500 \mathrm{MHz}, \mathrm{CDCl}_{3}\right): \delta 4.03(3 \mathrm{H}, \mathrm{s}), 5.52(2 \mathrm{H}, \mathrm{s})$, $6.91(1 \mathrm{H}, \mathrm{d}, J=7.4 \mathrm{~Hz}), 7.35(1 \mathrm{H}, \mathrm{dd}, J=7.4,8.6 \mathrm{~Hz}), 7.39-7.45(2 \mathrm{H}, \mathrm{m})$, 7.50-7.57 (2H, m), $7.59(1 \mathrm{H}, \mathrm{d}, J=8.6 \mathrm{~Hz}), 7.71(1 \mathrm{H}, \mathrm{d}, J=8.6 \mathrm{~Hz}), 7.71(1 \mathrm{H}$, d, $J=8.6 \mathrm{~Hz}), 7.88(1 \mathrm{H}, \mathrm{d}, J=7.4 \mathrm{~Hz}), 7.97(1 \mathrm{H}, \mathrm{d}, J=8.6 \mathrm{~Hz}), 7.97(1 \mathrm{H}, \mathrm{d}$, $J=8.6 \mathrm{~Hz}), 8.19(1 \mathrm{H}, \mathrm{d}, J=8.0 \mathrm{~Hz}), 8.36(1 \mathrm{H}, \mathrm{s}), 8.86(1 \mathrm{H}, \mathrm{s}) ;{ }^{13} \mathrm{C} \mathrm{NMR}$ $\left(125 \mathrm{MHz}, \mathrm{CDCl}_{3}\right): \delta 63.9,66.0,103.7,121.4,121.9,123.0,125.2,125.8,125.9$, $126.0,126.1$ (2C), 126.4, 126.9, 127.2, 127.8, 128.5, 128.6, 128.9, 129.5, 131.9, 132.7, 133.4, 135.7, 155.2, 155.3. (Found: C, 85.38; H, 5.38\%. Calculated for $\mathrm{C}_{26} \mathrm{H}_{20} \mathrm{O}_{2}:$ C, 85.69; $\left.\mathrm{H}, 5.53 \%\right)$.

1-(3-Methoxynaphthalen-2-ylmethyloxy)anthracene (1f), mp $160.5-162.0^{\circ} \mathrm{C}$; IR $\left(\mathrm{KBr}, \mathrm{cm}^{-1}\right): 1269 ;{ }^{1} \mathrm{H}$ NMR $\left(500 \mathrm{MHz}, \mathrm{CDCl}_{3}\right): \delta 3.98(3 \mathrm{H}, \mathrm{s}), 5.50(2 \mathrm{H}, \mathrm{s})$, $6.85(1 \mathrm{H}, \mathrm{d}, J=7.4 \mathrm{~Hz}), 7.19(1 \mathrm{H}, \mathrm{s}), 7.34(1 \mathrm{H}, \mathrm{dd}, J=7.4,8.0 \mathrm{~Hz}), 7.34(1 \mathrm{H}, \mathrm{dd}$, $J=7.4,8.0 \mathrm{~Hz}), 7.43-7.47(3 \mathrm{H}, \mathrm{m}), 7.59(1 \mathrm{H}, \mathrm{d}, J=8.0 \mathrm{~Hz}), 7.77(1 \mathrm{H}, \mathrm{d}, J=8.0$ 
$\mathrm{Hz}), 7.79(1 \mathrm{H}, \mathrm{d}, J=8.0 \mathrm{~Hz}), 7.98(1 \mathrm{H}, \mathrm{d}, J=9.2 \mathrm{~Hz}), 8.06-8.08(2 \mathrm{H}, \mathrm{m}), 8.38$ $(1 \mathrm{H}, \mathrm{s}), 9.00(1 \mathrm{H}, \mathrm{s}) ;{ }^{13} \mathrm{C} \mathrm{NMR}\left(125 \mathrm{MHz}, \mathrm{CDCl}_{3}\right): \delta 55.5,65.8,103.3,105.1$, $120.6,121.3,123.8,125.1,125.3,125.4,125.6,125.7,126.3,126.5,127.1,127.4$, $127.8,127.9,128.6,128.8,131.2,132.0,132.7,134.1,154.6,155.4$. (Found: C, 85.57; $\mathrm{H}, 5.46 \%$. Calculated for $\mathrm{C}_{26} \mathrm{H}_{20} \mathrm{O}_{2}$ : C, 85.69; $\mathrm{H}, 5.53 \%$ ).

1-(3,5-Dimethoxybenzyloxy)anthracene (1g), mp 111.0-112.0 ${ }^{\circ} \mathrm{C}$; IR ( $\mathrm{KBr}$, $\left.\mathrm{cm}^{-1}\right): 1209 ;{ }^{1} \mathrm{H}$ NMR $\left(500 \mathrm{MHz}, \mathrm{CDCl}_{3}\right): \delta 3.81(3 \mathrm{H}, \mathrm{s}), 3.81(3 \mathrm{H}, \mathrm{s}), 5.24$ $(2 \mathrm{H}, \mathrm{s}), 6.47(1 \mathrm{H}, \mathrm{s}), 6.73(1 \mathrm{H}, \mathrm{s}), 6.73(1 \mathrm{H}, \mathrm{s}), 6.76(1 \mathrm{H}, \mathrm{d}, J=7.4 \mathrm{~Hz}), 7.32$ $(1 \mathrm{H}, \mathrm{dd}, J=7.4,8.6 \mathrm{~Hz}), 7.42-7.57(2 \mathrm{H}, \mathrm{m}), 7.58(1 \mathrm{H}, \mathrm{d}, J=8.6 \mathrm{~Hz}), 7.97(1 \mathrm{H}$, $\mathrm{d}, J=9.2 \mathrm{~Hz}), 8.03(1 \mathrm{H}, \mathrm{d}, J=9.2 \mathrm{~Hz}), 8.36(1 \mathrm{H}, \mathrm{s}), 8.91(1 \mathrm{H}, \mathrm{s}) ;{ }^{13} \mathrm{C}$ NMR $\left(125 \mathrm{MHz}, \mathrm{CDCl}_{3}\right): \delta 55.4,55.5,70.1,99.8,103.1,105.3,120.7,120.8,121.2$, $125.1,125.2,125.3,125.6,125.7,127.9,128.8,131.2,131.9,132.6,139.5,154.4$, 161.0, 161.1. (Found: C, 80.12; H, 5.48\%. Calculated for $\mathrm{C}_{23} \mathrm{H}_{20} \mathrm{O}_{3}$ : C, 80.21; $\mathrm{H}, 5.85 \%)$

The St and $\mathrm{CHO}$ monomers were purified by vacuum distillation before they were used. All other chemicals were obtained from commercial sources at the highest grade available (Wako, Osaka, Japan and Tokyokasei, Tokyo, Japan).

\section{Measurements}

Changes in the UV absorption spectra for $1 \mathrm{a}-\mathrm{g}\left(2.0 \times 10^{-4} \mathrm{~mol} \mathrm{dm}^{-3}\right)$ were observed at room temperature in nitrogen-saturated toluene or 1,2-dimethoxy ethane $(25 \mathrm{ml})$ by irradiation with a $500-\mathrm{W}$ high-pressure $\mathrm{Hg}$ lamp at wavelengths greater than $340 \mathrm{~nm}$ (Corning 0-52 and Toshiba IRA-25S glass filters). The irradiation intensity was $170 \mathrm{~mW} \mathrm{~cm}^{-2}$.

For the analysis of the photoproducts derived from la- $\mathrm{g}\left(2.0 \times 10^{-3} \mathrm{~mol} \mathrm{dm}^{-3}\right)$, solutions of these photoinitiators in nitrogen-saturated toluene or 1,2-dimethoxyethane $(25 \mathrm{ml})$ in Pyrex vessels were irradiated with a 500-W high-pressure $\mathrm{Hg}$ lamp at room temperature for $2-4 \mathrm{~min}$ at wavelengths greater than $340 \mathrm{~nm}$ (Corning 0-52 and Toshiba IRA-25S glass filters). The irradiated solutions were subjected to HPLC analysis (mobile phase, $\mathrm{MeCN}-\mathrm{H}_{2} \mathrm{O}(60: 40 \mathrm{v} / \mathrm{v})$; detection wavelength, $240 \mathrm{~nm}$ ). The structures of the photoproducts were determined by comparing the HPLC data (retention times and shapes of the HPLC signals) of the products with those of commercially available authentic samples.

A specified amount of $\mathbf{1}$ was dissolved in St or $\mathrm{CHO}$ in a glass tube and the resulting solution was degassed by three freeze-pump-thaw cycles. The sealed glass tube was maintained at a given temperature and irradiated by a $500-\mathrm{W}$ high-pressure Hg lamp at wavelengths greater than $340 \mathrm{~nm}$ (Corning 0-52 and Toshiba IRA-25S glass filters). The reaction mixture, which was irradiated for a given period of time, was poured into aqueous methanol. The resultant polymer that precipitated was filtered and dried in vacuo at $40^{\circ} \mathrm{C}$. The polymer yield was estimated gravimetrically using an average of more than two measurements.

IR spectra were recorded on a Shimadzu Prestige-21 IR spectrophotometer (Shimadzu Corporation, Kyoto, Japan). ${ }^{1} \mathrm{H}$ and ${ }^{13} \mathrm{C}$ NMR spectra were recorded on a JEOL JNM-A500 spectrometer (JEOL, Tokyo, Japan) at 500 and $125 \mathrm{MHz}$, respectively, in $\mathrm{CDCl}_{3}$ with tetramethylsilane as an internal standard. Elemental analysis was performed on a Perkin-Elmer 2400 series II CHNS/O analyzer (Waltham, MA, USA). Irradiation intensity was measured by a UV-M03 intensity meter (ORC, Tokyo, Japan) equipped with a UV-SN35-M10 photodetector (ORC). UV absorption and fluorescence spectra were collected on a Hitachi U-3300 spectrophotometer and a Hitachi F-4500 spectrofluorimeter (Hitachi, Tokyo, Japan), respectively. HPLC analysis was conducted on a Shimadzu LC-10AT $T_{\text {VP }}$ HPLC system (Shimadzu Corporation) equipped with a $4.6 \times 250$-mm ODS (Zorbax) column and a Shimadzu SPD-10AVP UV detector (Shimadzu Corporation). The molecular weight distribution of the polymers were estimated by gel permeation chromatography using a Tosoh model HLC-8020 gel permeation chromatography unit (Tosoh Corporation, Tokyo, Japan) equipped with a refractive index detector using two TSK-gel columns (Multipore $\mathrm{H}_{\mathrm{XL}^{-}}$ $\mathrm{M} \times 2$ ) and tetrahydrofuran as an eluent. A calibration curve for molecular weights ranging from 500 to $1.11 \times 10^{6}$ was obtained under conditions similar to those used for standard PSt.

\section{RESULTS AND DISCUSSION}

\section{Photoreactivity of 1a-g}

As typically shown in Figures 2 and 3, the 1-arylmethyloxyanthracene derivative 1c $\left(2.0 \times 10^{-4} \mathrm{~mol} \mathrm{dm}^{-3}\right)$ exhibited vibrational bands near 340 (molar absorption coefficient, $\varepsilon=4380 \mathrm{dm}^{3} \mathrm{~mol}^{-1} \mathrm{~cm}^{-1}$ ), 350 (3680), 370 (4770) and $390 \mathrm{~nm}$ (3680) in both toluene (Figure 2) and 1,2-dimethoxyethane (Figure 3). These bands were derived from the anthracene ring. The relatively large absorbance at $\sim 340 \mathrm{~nm}$ is due to the presence of the 2-methoxynaphthyl chromophore producing the first absorption band at $323\left(\varepsilon=2410 \mathrm{dm}^{3} \mathrm{~mol}^{-1} \mathrm{~cm}^{-1}\right)$ and $336 \mathrm{~nm}$ (2690). After irradiating the anthryloxy chromophore with light by a $500-\mathrm{W}$ high-pressure $\mathrm{Hg}$ lamp in nitrogen-saturated toluene at wavelengths greater than $340 \mathrm{~nm}$, several absorption bands

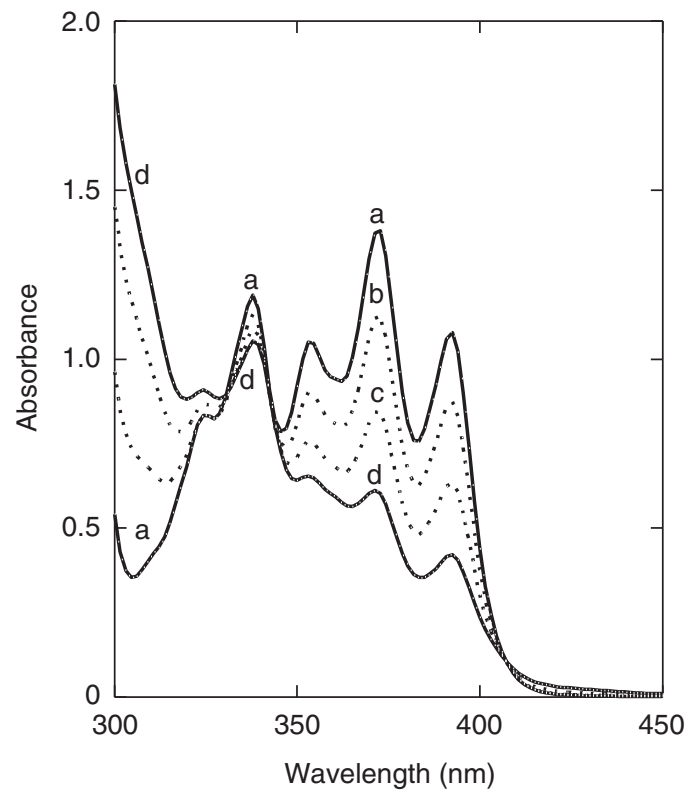

Figure 2 The UV absorption spectral changes caused by irradication $(\lambda>340 \mathrm{~nm})$ of $1 \mathrm{c}\left(2.0 \times 10^{-4} \mathrm{~mol} \mathrm{dm}^{-3}\right)$ in nitrogen-saturated toluene at room temperature. The irradiation times were 0 (curve a), $10 \mathrm{~s}$ (curve b), $30 \mathrm{~s}$ (curve c) and $60 \mathrm{~s}$ (curve d).

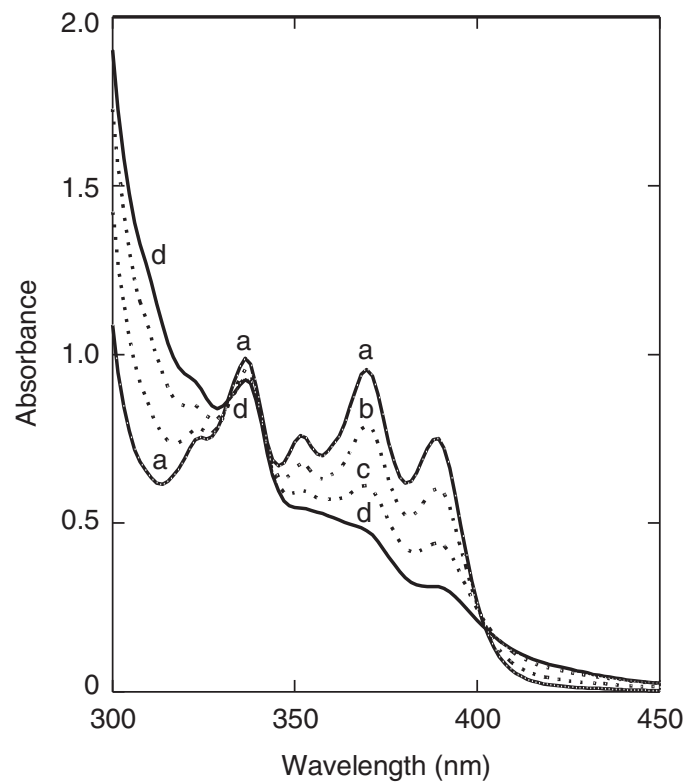

Figure 3 The UV absorption spectral changes caused by irradication $(\lambda>340 \mathrm{~nm})$ of $1 \mathrm{c}\left(2.0 \times 10^{-4} \mathrm{~mol} \mathrm{dm}^{-3}\right)$ in nitrogen-saturated 1,2-dimethoxyethane at room temperature. The irradiation times were 0 (curve a), $10 \mathrm{~s}$ (curve b), $30 \mathrm{~s}$ (curve c) and $60 \mathrm{~s}$ (curve d). 
originating from the anthracene ring decreased, and new absorption bands in the 300-330 $\mathrm{nm}$ region appeared (Figure 2). Similar changes in the absorption spectra were observed in the more polar solvent, 1,2-dimethoxyethane (Figure 3) and for other anthracene derivatives. As the irradiated light is not absorbed by the arylmethyl chromophore in the initiator $\mathbf{1}$ and is exclusively absorbed by the anthryloxy chromophore, the rate (in the initial stage of the photolysis of this initiator) at which the $370 \mathrm{~nm}$ absorption from the latter chromophore decreases can be used instead of the quantum yield for the initiator photolysis and, hence, becomes a measure of the photoreactivity of $\mathbf{1}$. To compare the photoreactivities of $\mathbf{1 a}-\mathbf{g}$, we determined the extent to which the absorbance at $390 \mathrm{~nm}$ decreased each second in the initial stage of the reactions. In toluene, this extent was $1 \mathbf{c}\left(1.5 \times 10^{-2}\right)>\mathbf{l b}\left(1.1 \times 10^{-2}\right)>\mathbf{1 d}\left(5.1 \times 10^{-3}\right)>\mathbf{l a}$ $\left(3.9 \times 10^{-3}\right)>$ lf $\left(2.4 \times 10^{-3}\right)>1$ e $\left(2.1 \times 10^{-3}\right)>1$ g $\left(1.7 \times 10^{-3}\right)$; however, in 1,2-dimethoxyethane, the reactivity order of $\mathbf{1 a}$ was greater than that of $\mathbf{1 d}$, and the reactivity order of $\mathbf{1 e}$ was greater than that of 1f. These findings demonstrate that the 1-naphthyl-substituted anthracene initiators $\mathbf{1 a - d}$ are more reactive than the 2-naphthyl- and phenyl-substituted initiators $1 \mathbf{e}-\mathbf{g}$. They also suggest that the type of bond cleavage promoted by $\mathbf{1}$ in toluene and 1,2-dimethoxyethane differ. Of note, a comparison of the photoreactivities for initiators la-c revealed that an increase in the electron-donating ability of substituent $R^{1}$ (Figure 1) enhanced the reactivity of the initiator. In addition, $1 \mathrm{c}$ with the 2-methoxy substituent was shown to be more reactive than its isomer 1d. Based on the relationships between irradiation time and conversion of given reactants in the photolyses of the initiator 1c and 1-(9-anthryl) methyloxy-2-pyridone with a structure related to this initiator, ${ }^{26}$ the quantum yield for the former photolysis ( 0.07 for the latter photolysis) was estimated to be on the order of $10^{-1}$. The above-mentioned effects of substituents on the photoreactivity allow us to propose that there is either a charge-transfer interaction between two aromatic chromophores in the excited state or a recombination of a radical pair or ion pair intermediate that influences the photoreactivity of $\mathbf{1}$. If a chargetransfer interaction in the excited state controls this photoreactivity, the reactivity order for $\mathbf{1 a}-\mathbf{c}$ demonstrates that the substituted naphthyl group acts as an electron donor. As an excited-state bichromophoric interaction should be directly reflected in the emission behavior of a given molecule, ${ }^{15}$ the fluorescence spectra of methoxy-substituted derivatives $\mathbf{1} \mathbf{c}-\mathbf{g}$ were measured (Figures 4 and 5). Clearly, there are no significant differences in the maximum fluorescence wavelength and intensity of these derivatives in both toluene and 1,2-dimethoxyethane, suggesting a minor contribution of the above-described excited-state interaction to photoreactivity. Thus, we conclude that an increase in the stability of a radical pair or ion pair intermediate suppresses the recombination of the intermediate, resulting in a net enhancement of photoreactivity.

To investigate the magnitude of intramolecular charge separation in the excited-state anthryloxy chromophore, the dissociation constant $\left(\mathrm{p} K_{\mathrm{a}}\right)$ of 1-hydroxyanthracene in the singlet ground and excited states was estimated by measuring the $\mathrm{pH}$ dependence of its UV absorption and fluorescence spectra in nitrogen-saturated water containing $0.10 \mathrm{~mol} \mathrm{dm}^{-3} \mathrm{KCl}$. The $\mathrm{p} K_{\mathrm{a}}$ values in the ground (9.6) and excited (4.2) states confirm that a charge-separated state is established during the excited-state lifetime. This greatly enhances the acidity of this derivative, as evidenced by the difference in $\mathrm{p} K_{\mathrm{a}}$ values $\left(\Delta \mathrm{p} K_{\mathrm{a}}=5.4\right)$, which is comparable to that of phenol (6.4) and 2-naphthol (6.4). ${ }^{16}$ From this finding, we predict that in $\mathrm{CHO}$, heterolytic $\mathrm{CH}_{2}-\mathrm{OAr}$ bond cleavage takes place efficiently in competition with homolytic $\mathrm{CH}_{2} \mathrm{O}-\mathrm{Ar}$ bond cleavage in the excited state of 1 . A previous study

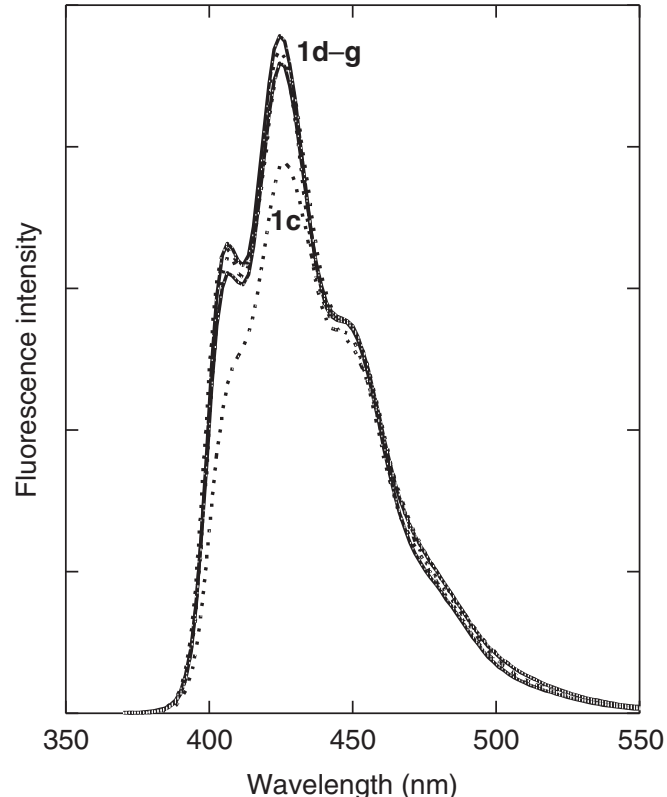

Figure 4 The fluorescence spectra of $1 \mathrm{c}-\mathrm{g}\left(2.0 \times 10^{-4} \mathrm{~mol} \mathrm{dm}^{-3}\right)$ in nitrogen-saturated toluene at room temperature. The excitation wavelength was $339 \mathrm{~nm}$.

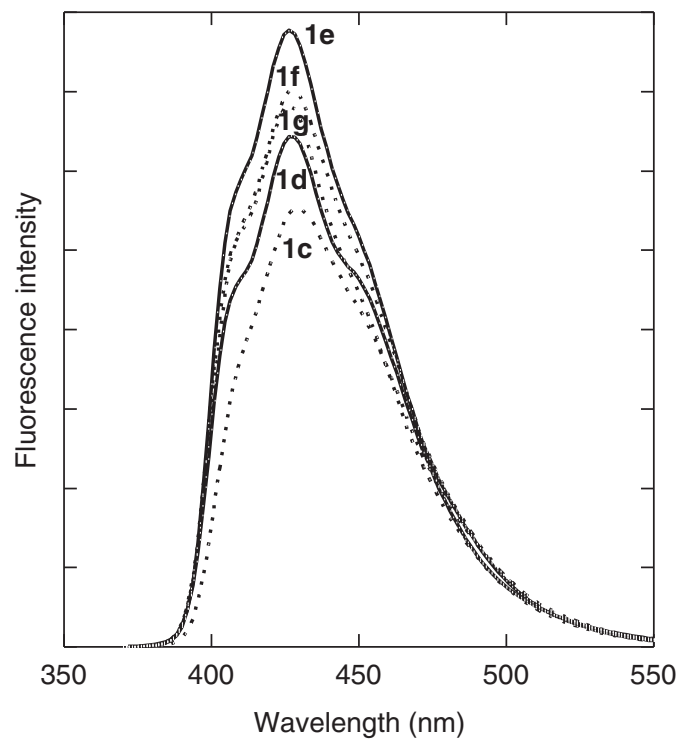

Figure 5 The fluorescence spectra of $1 \mathrm{c}-\mathbf{g}\left(2.0 \times 10^{-4} \mathrm{~mol} \mathrm{dm}^{-3}\right)$ in nitrogen-saturated 1,2-dimethoxyethane at room temperature. The excitation wavelength was $339 \mathrm{~nm}$.

showed that the photolysis of 6-cyano-2-(9-anthrylmethyloxy) naphthalene in 1,2-dimethoxyethane (employed instead of $\mathrm{CHO}$ ) generates 6-cyano-2-hydroxynaphthalene and anthracene-9-methanol as heterolytic $\mathrm{CH}_{2}-\mathrm{OAr}$ bond cleavage products. Conversely, only the homolytic $\mathrm{CH}_{2} \mathrm{O}-\mathrm{Ar}$ bond cleavage products, 6-cyanonaphthalene, anthracene-9-carbaldehyde and anthracene-9-methanol, are detected upon irradiation in toluene (used as an alternative to St). ${ }^{17}$ Thus, the product distribution analysis can reliably distinguish the mode of bond cleavage for bichromophoric photoinitiators. Considering the above-mentioned product distribution, $\mathbf{1 c}$ and $\mathbf{1 d}$ were chosen as model initiators, and the 1-derived product distribution was 


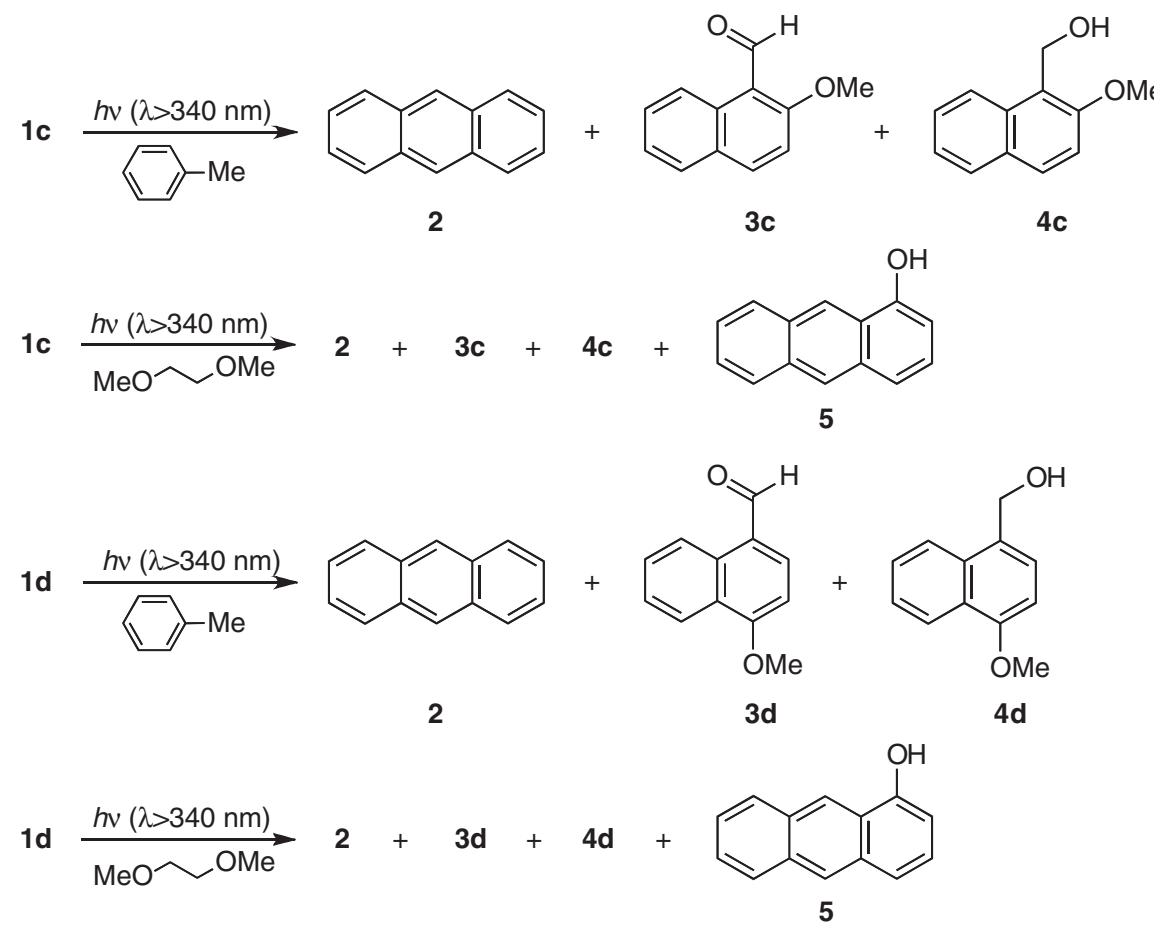

Scheme 1 Major products that were derived from the photolysis of $\mathbf{1} \mathbf{c}$ and $\mathbf{1 d}$ in toluene and 1,2-dimethoxyethane at room temperature.

examined by comparing HPLC data for the photoproducts with those of authentic samples. As shown in Scheme 1, the irradiation of a nitrogen-saturated toluene solution of $1 \mathrm{c}\left(2.0 \times 10^{-3} \mathrm{~mol} \mathrm{dm}^{-3}\right)$ at wavelengths longer than $340 \mathrm{~nm}$ produced anthracene (2, 18\% HPLC yield), 1-formyl-2-methoxynaphthalene (3c, 7\%) and 1-hydroxymethyl-2-methoxynaphthalene $(4 \mathrm{c}, 6 \%)$ at $35 \%$ conversion. On the basis of the above criterion, we confirmed that the homolysis of the $\mathrm{CH}_{2} \mathrm{O}-\mathrm{Ar}$ bond takes place predominantly in toluene. Homolytic cleavage of this bond should form anthracen-1-yl and 2-methoxynaphthalen-1-ylmethyloxyl radicals as precursors of $2,3 \mathrm{c}$ and $4 \mathrm{c}$. Hydrogen abstraction of these radicals from the solvent gives 2 and 4c. At the same time, $3 \mathrm{c}$ must be derived along with 2 from the hydrogen abstraction of the former radical from the latter in a given solvent cage. On the other hand, upon irradiation in nitrogensaturated 1,2-dimethoxyethane under the same conditions, 1-hydroxyanthracene $(5,13 \%)$ was detected $(35 \%$ conversion, Scheme 1$)$ in addition to these products $(2,2 \% ; 3 c, 4 \% ; 4 c, 11 \%)$. Based on the structures of arylmethyl carbocation-derived products in nucleophilic polar solvents, ${ }^{27}$ it is reasonable to assume that 1-hydroxyanthracene (5) and part of 1-hydroxymethyl-2-methoxynaphthalene (4c) arise from the hydrolytic reaction of anthracen-1-yloxy anion and 2-methoxynaphthalen-1-ylmethyl carbocation in 1,2-dimethoxyethane, possibly containing trace amounts of water.

On the other hand, there were several additional signals along with those of $1 c, 2,3 c, 4 c$ and 5 in the HPLC chromatogram. The presence of these unidentified HPLC signals is considered to be responsible for the moderate material balance observed in the photolysis of 1c (40-50\% in toluene and $40 \%$ in 1,2-dimethoxyethane). Control experiments in the latter solvent confirmed that some unidentified signals are attributable to the 5-derived secondary products.
In addition, the high electrophilicity of the arylmethyloxyl radical and arylmethyl carbocation enables these reactive intermediates to form the corresponding adducts with toluene and 1,2-dimethoxyethane, respectively; a decrease in the material balance of the photoproducts $\mathbf{2}-\mathbf{5}$ results from this reaction. Although attempts to isolate products that could not be identified by HPLC analysis were unsuccessful, the above considerations allow us to conclude that the photodecomposition of $\mathbf{1}$ in 1,2-dimethoxyethane proceeds via both homolytic $\mathrm{CH}_{2} \mathrm{O}-\mathrm{Ar}$ and heterolytic $\mathrm{CH}_{2}-\mathrm{OAr}$ bond cleavage modes This conclusion is also supported by the finding that $1 \mathbf{d}\left(2.0 \times 10^{-}\right.$ $\left.{ }^{3} \mathrm{~mol} \mathrm{dm}^{-3}\right)$, the positional isomer of $\mathbf{1 c}$, also undergoes efficient photodecomposition under the same conditions to produce $2(21 \%$ in toluene (conversion, 35\%); 3\% in 1,2-dimethoxyethane (conversion, $30 \%)$ ), $3 \mathbf{d}$ (7\% in toluene; $4 \%$ in 1,2-dimethoxyethane), $4 \mathbf{d}(6 \%$ in toluene; $11 \%$ in 1,2-dimethoxyethane) and $5(\approx 0 \%$ in toluene; $12 \%$ in 1,2-dimethoxyethane) (Scheme 1).

\section{Photopolymerization with $1 \mathrm{a}-\mathrm{g}$}

The product analysis described in the preceding section indicated that 1-(arylmethyloxy)anthracene initiators generate the arylmethyloxyl radical and arylmethyl carbocation through photolysis, allowing them to function as hybrid-type photoinitiators in polymerizations of St and CHO. Tables 1 and 2 summarize the yields, number-average molecular weights $\left(M_{\mathrm{n}}\right)$, and polydispersities $\left(M_{\mathrm{w}} / M_{\mathrm{n}}, M_{\mathrm{w}}\right.$ : weightaverage molecular weights) of PSt and PCHO obtained by the bulk photopolymerization of St and $\mathrm{CHO}$ in the presence of 1a-g. These initiators were irradiated with light at wavelengths greater than $340 \mathrm{~nm}$ at room temperature or at $60^{\circ} \mathrm{C}$. Control experiments demonstrated that the irradiation of St and $\mathrm{CHO}$ for $8 \mathrm{~h}$ at $60^{\circ} \mathrm{C}$ without an initiator produced the corresponding polymers in minor 
Table 1 Photopolymerization of St with $1 \mathrm{a}-\mathrm{g}$ as initiators $\mathrm{a}^{\mathrm{a}}$

\begin{tabular}{lccccc}
\hline Initiator & Time (h) & Temperature $(\mathrm{C})$ & Yield (\%) & $M_{\mathrm{n}} \times 10^{-4}$ & $M_{\mathrm{w}} M_{\mathrm{n}}$ \\
\hline 1a & 8 & $\mathrm{RT}$ & 15.7 & 2.0 & 3.2 \\
& 8 & 60 & 31.5 & 3.2 & 2.8 \\
& 12 & 60 & 44.9 & 5.6 & 2.9 \\
1b & 8 & $\mathrm{RT}$ & 19.7 & 2.1 & 2.4 \\
& 8 & 60 & 36.7 & 3.1 & 2.9 \\
& 12 & 60 & 64.2 & 5.7 & 3.1 \\
1c & 8 & $\mathrm{RT}$ & 24.3 & 2.1 & 2.4 \\
& 8 & 60 & 57.8 & 3.2 & 3.0 \\
& 12 & 60 & 76.5 & 5.9 & 3.2 \\
1d & 8 & $\mathrm{RT}$ & 13.8 & 3.4 & 2.4 \\
& 8 & 60 & 21.1 & 4.2 & 2.9 \\
& 12 & 60 & 42.8 & 7.1 & 3.0 \\
1e & 8 & $\mathrm{RT}$ & 5.8 & 3.2 & 2.7 \\
& 8 & 60 & 13.4 & 3.4 & 2.6 \\
& 12 & 60 & 24.0 & 5.7 & 3.2 \\
1f & 8 & $\mathrm{RT}$ & 7.8 & 2.9 & 2.7 \\
& 8 & 60 & 19.0 & 4.8 & 2.7 \\
& 12 & 60 & 34.9 & 6.8 & 2.8 \\
1g & 8 & RT & 5.2 & 6.8 & 2.3 \\
& 8 & 60 & 8.9 & 10.3 & 2.7 \\
& 12 & 60 & 15.6 & 11.1 & 2.6 \\
\hline
\end{tabular}

Abbreviation: RT, room temperature.

a Initiator] $/[\mathrm{St}]=0.2 \mathrm{~mol} \%$. The initiator was irradiated with $\lambda>340 \mathrm{~nm}$.

Table 2 Photopolymerization of $\mathrm{CHO}$ with $1 \mathrm{a}-\mathrm{g}$ as initiators ${ }^{\mathrm{a}}$

\begin{tabular}{|c|c|c|c|c|c|}
\hline Initiator & Time $(h)$ & Temperature $\left({ }^{\circ} \mathrm{C}\right)$ & Yield (\%) & $M_{\mathrm{n}} \times 10^{-4}$ & $M_{\mathrm{w}} / M_{\mathrm{n}}$ \\
\hline \multirow[t]{3}{*}{$1 a$} & 8 & RT & $<1$ & - & - \\
\hline & 8 & 60 & 5.8 & 0.6 & 1.5 \\
\hline & 16 & 60 & 15.4 & 0.6 & 1.5 \\
\hline \multirow[t]{3}{*}{$1 b$} & 8 & $\mathrm{RT}$ & 13.8 & 0.7 & 1.4 \\
\hline & 8 & 60 & 34.9 & 0.7 & 1.6 \\
\hline & 16 & 60 & 52.1 & 1.4 & 1.8 \\
\hline \multirow[t]{3}{*}{ 1c } & 8 & $\mathrm{RT}$ & 22.3 & 0.7 & 1.7 \\
\hline & 8 & 60 & 50.4 & 1.9 & 1.8 \\
\hline & 16 & 60 & 62.7 & 1.6 & 1.7 \\
\hline \multirow[t]{3}{*}{$1 d$} & 8 & RT & 14.3 & 1.3 & 1.6 \\
\hline & 8 & 60 & 34.1 & 1.8 & 1.6 \\
\hline & 16 & 60 & 46.1 & 1.1 & 1.8 \\
\hline \multirow[t]{3}{*}{$1 \mathrm{e}$} & 8 & RT & 13.0 & 1.4 & 1.8 \\
\hline & 8 & 60 & 23.0 & 1.6 & 1.8 \\
\hline & 16 & 60 & 45.1 & 2.0 & 1.9 \\
\hline \multirow[t]{3}{*}{$1 f$} & 8 & RT & 10.0 & 1.4 & 1.8 \\
\hline & 8 & 60 & 14.5 & 1.3 & 1.8 \\
\hline & 16 & 60 & 39.3 & 1.9 & 1.8 \\
\hline \multirow[t]{3}{*}{$1 g$} & 8 & RT & 9.5 & 1.7 & 1.7 \\
\hline & 8 & 60 & 17.1 & 1.4 & 1.8 \\
\hline & 16 & 60 & 27.7 & 1.5 & 1.8 \\
\hline
\end{tabular}

${ }^{a}[$ Initiator $] /[\mathrm{CHO}]=0.2 \mathrm{~mol} \%$. The initiator was irradiated with $\lambda>340 \mathrm{~nm}$

(5\%) and negligible yields, respectively. Moreover, the presence of 2,2,6,6-tetramethylpiperidinyl-1-oxy $(0.2 \mathrm{~mol} \%)$ completely inhibited the polymerization of St but had no influence on $\mathrm{CHO}$ polymerization, confirming the requirement of a radical mechanism for polymerization in the former case. The data in Tables 1 and 2 show that polymer yields increase with the polymerization temperature, irradiation time and electron-donating ability of 2-substituted naphthalen-1-yl group. Although increased reaction time and temperature tend to render larger values of $M_{\mathrm{n}}$ and $M_{\mathrm{w}} / M_{\mathrm{n}}$ for PSt, this tendency was not observed for PCHO.

These results substantiate the participation of a radical mechanism in the photopolymerization of St. We interpret the observation that $M_{\mathrm{n}}$ tends to increase with the yield of 1-derived PSt in terms of the photodissociation of the polymer end group and subsequent repolymerization by propagating radicals. ${ }^{7}$ The yield of PSt may be used as a measure of the ability of the arylmethyloxyl radical to initiate the polymerization of St. Accordingly, the finding that the photoreactivity order of $1 \mathrm{a}-\mathrm{g}$ in toluene $(\mathbf{1 c}>\mathbf{1 b}>\mathbf{1 d}>\mathbf{1 a}>\mathbf{1 f}>\mathbf{1 e}>\mathbf{1 g})$ corresponds well with the yield order of PSt that was obtained by the $12 \mathrm{~h}$ irradiation of $\mathbf{1}$ at $60^{\circ} \mathrm{C}(\mathbf{1 c}>\mathbf{l b}>\mathbf{1 a} \geqslant \mathbf{1 d}>\mathbf{1 f}>\mathbf{1 e}>\mathbf{1 g}$, Table 1) demonstrates that the ability of the arylmethyloxyl radical to initiate the polymerization of St increases with increasing radical stability. As previously described, the decrease in the stability of the arylmethyloxyl/anthryl radical pair is likely to cause further deactivation by the recombination of the pair. Conversely, a comparison of the reactivity order in 1,2-dimethoxyethane $(\mathbf{1 c}>\mathbf{1 b}>\mathbf{1 a}>\mathbf{1 d}>$ 1e $>$ 1f $>$ 1g) with the yield order of $\mathrm{PCHO}$ obtained by the $16 \mathrm{~h}$ irradiation of $\mathbf{1}$ at $60^{\circ} \mathrm{C}$ reported in Table $2(\mathbf{1 c}>\mathbf{1 b}>$ 1d $>$ le $>$ 1f $>$ 1g $>$ 1a) generally supports this relationship, except for 1a. As the initiator 1 in the excited state undergoes both homolytic and heterolytic bond cleavage in 1,2-dimethoxyethane and the polymerization of $\mathrm{CHO}$ takes place by an ionic mechanism, this finding suggests that the ability of $\mathbf{1 a}$ to initiate the cationic polymerization of $\mathrm{CHO}$ is much lower than expected from the photoreactivity of this initiator. It is likely that without a substituent on the naphthalene ring, the naphthalen-1-ylmethyl carbocation is more susceptible to deactivation by water contaminants in $\mathrm{CHO}$ than the other substituted naphthalen-1-ylmethyl carbocations. At the same time, the discovery that the ability of $\mathbf{1 g}$ to initiate cationic polymerization is comparable to that of 1 f suggests the major role of

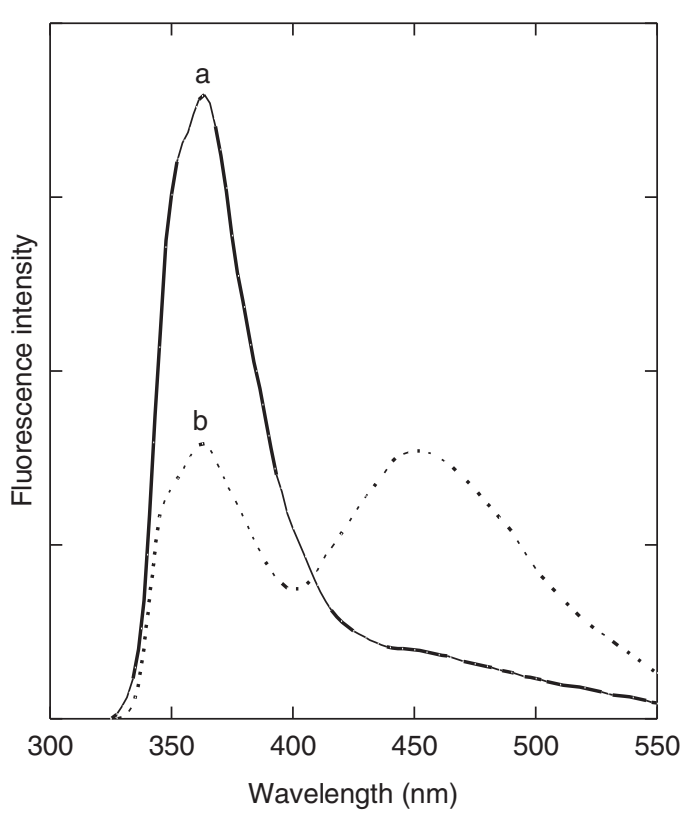

Figure 6 The fluorescence spectra of PSt (curve a, $0.50 \mathrm{~g} \mathrm{dm}^{-3}$ ) and PCHO (curve b, $0.50 \mathrm{~g} \mathrm{dm}^{-3}$ ), obtained by the irradication $(\lambda>340 \mathrm{~nm})$ of St and $\mathrm{CHO}$ in the presence of $0.2 \mathrm{~mol} \% 1 \mathrm{c}$ at room temperature, respectively, in nitrogen-saturated chloroform at room temperature. The excitation wavelength was $283 \mathrm{~nm}$. 


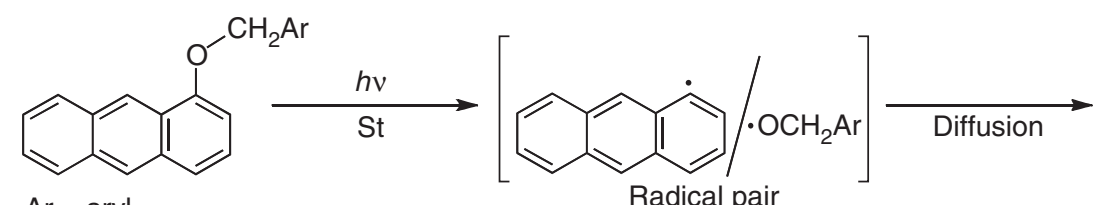

$\mathrm{Ar}=\operatorname{aryl}$

Radical pair

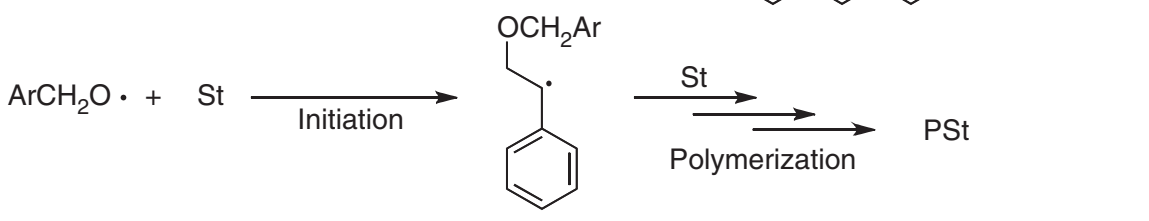

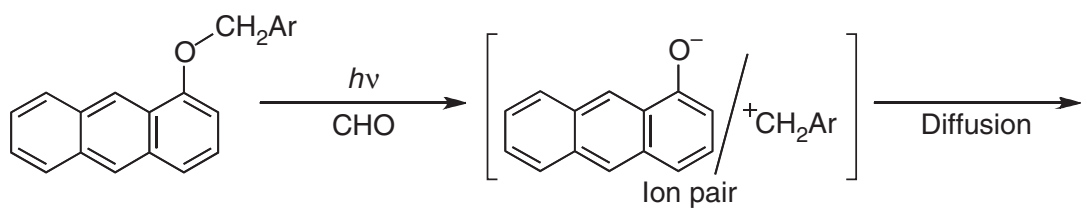

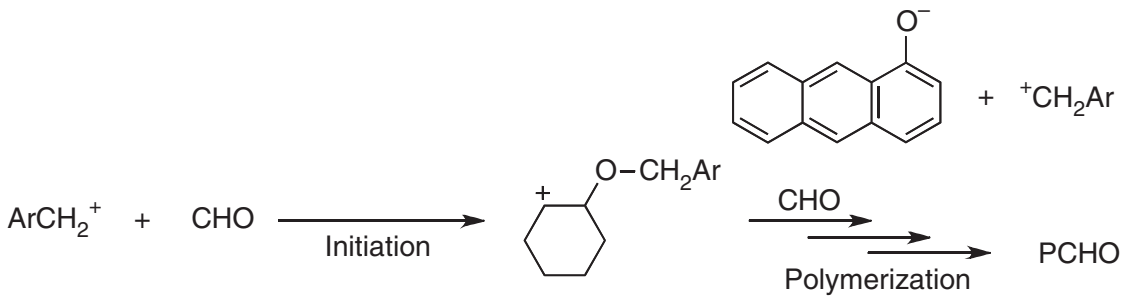

Scheme 2 Plausible initiation mechanisms for the photopolymerization reactions of St and $\mathrm{CHO}$ in the presence of 1.

the 'meta effect' in the former initiator when it is in the excited state and performing bond cleavage. The two methoxy groups in $1 \mathrm{~g}$ are considered to exert the above effect when the initiator is excited inducing efficient heterolytic $\mathrm{CH}_{2}-\mathrm{OAr}$ bond cleavage in competition with homolytic $\mathrm{CH}_{2} \mathrm{O}-\mathrm{Ar}$ bond cleavage ( $\mathrm{Ar}=1$-anthryl). Therefore, the relationship between the reactivity order of 1 in 1,2-dimethoxy ethane and the yield order of PCHO led us to conclude that the stability of the arylmethyl carbocation formed in this solvent is a major factor in controlling the polymer yield.

To analyze the polymer end groups, ${ }^{1} \mathrm{H}$ NMR and fluorescence spectra were recorded for the PSt $\left(M_{\mathrm{n}}=8800\right)$ and PCHO (6900) that were produced by the photopolymerization with $1 \mathrm{c}(0.2 \mathrm{~mol} \%)$ at room temperature. Although the proton signals of all of the polymer end groups were undetectable by NMR, fluorescence spectra allowed the analysis of the structure of the end groups. As depicted in Figure 6, 1c-derived PSt exhibited an intense fluorescence at $365 \mathrm{~nm}$ and a weak emission near $450 \mathrm{~nm}$, whereas these two fluorescence bands were observed with an intensity ratio near 1 for PCHO. The compounds 1-hydroxymethyl-2-methoxynaphthalene and 1-hydroxyanthracene displayed the maximum fluorescence intensities at 365 and $448 \mathrm{~nm}$, respectively. The former finding suggests that the 2-methoxynaphthalen-1-ylmethyloxy chromophore is a major end group of PSt, whereas the 1-anthryl end group has only a minor role. Moreover, the latter finding substantiated the existence of 2-methoxynaphthalen-1ylmethyl and 1-anthryloxy chromophores at the chain ends of PCHO. Thus, we conclude that the arylmethyloxyl radical and arylmethyl carbocation that are separated from the corresponding radical and ion pairs are involved in the initiation steps of photopolymerization reactions for St and $\mathrm{CHO}$, respectively, as shown in Scheme 2.

\section{ACKNOWLEDGEMENTS}

This research was partly supported by a 'Scientific Frontier Research Project' from the Ministry of Education, Sports, Culture, Science and Technology in Japan.

1 Crivello, J. V. \& Dietliker, K. in Photoinitiators for Free Radical, Cationic \& Anionic Photopolymerisation. 2nd edn (ed. Bradley, G.) (John Wiley and Sons, London, 1998).

2 Oxman, J. D., Jacobs, D. W. \& Trom, M. C. Controlled, sequentially curable cationic/ free radical hybrid photopolymerizations. Polym. Mater. Sci. Eng. 88, 239-240 (2003)

3 Kasapoglu, F., Aydin, M., Arsu, N. \& Yagci, Y. Photoinitiated polymerization of methyl methacrylate by phenacyl type salts. J. Photochem. Photobiol. 159, 151-159 (2003).

4 Takahashi, E., Sanda, F. \& Endo, T. Photocationic and radical polymerizations of epoxides and acrylates by novel sulfonium salts. J. Polym. Sci. 41, 3816-3827 (2003).

5 Takahashi, E., Sanda, F. \& Endo, T. Photocationic and radical polymerizations by novel N-phenacylammonium salts. J. Appl. Polym. Sci. 91, 3470-3476 (2004).

6 Hino, T. \& Endo, T. Cationic photopolymerization of an epoxide by substituted phenols as a novel nonsalt-type photolatent initiator. Macromolecules 37, 1671-1673 (2004).

7 Tanaka, K., Nakamura, K., Yoshioka, N., Kameyama, A., Igarashi, T. \& Sakurai, T. Abilities of 1-(9-anthrylmethyloxy)-2-pyridone and related compounds to initiate radical and cationic photopolymerizations. J. Polym. Sci. 42, 2859-2865 (2004).

8 Oxman, J. D., Jacobs, D. W., Trom, M. C. Sipani, V., Ficek, B. \& Scranton, A. B. Evaluation of initiator systems for controlled and sequentially curable free-radical/ cationic hybrid photopolymerizations. J. Polym. Sci. 43, 1747-1756 (2005).

9 Lin, M.-S. \& Wang, M.-W. Kinetic study on epoxy bisphenol-A diacrylate IPN formation. Polym. Int. 48, 1237-1243 (1999).

10 Decker, C., Nguyen Thi Viet, T., Decker, D. \& Weber-Koehl, E. UV-radiation curing of acrylate/epoxide systems. Polymer 42, 5531-5541 (2001).

11 Lecamp, L., Pavillon, C., Lebaudy, P. \& Bunel, C. Influence of temperature and nature of photoinitiator on the formation kinetics of an interpenetrating network photocured from an epoxide/methacrylate system. Eur. Polym. J. 41, 169-176 (2005).

12 Al-Doaiss, A. A., Günther, W., Klemm, E. \& Stadermann, D. Photoinitiated cationic polymerization of substituted vinylcyclopropanes. Macromol. Chem. Phys. 206, 2348-2353 (2005). 
13 Yonet, N., Bicak, N. \& Yagci, Y. Photoinitiated cationic polymerization of cyclohexene oxide by using phenacyl benzoylpyridinium salts. Macromolecules 39, 2736-2738 (2006).

14 Tanaka, K., Takahashi, Y., Isobe, T., Satoh, T., Akimoto, R., Igarashi, T. \& Sakurai, T. Bond-cleavage mode of $O$-acyl anthracene-9-methanol derivatives in the singlet excited state and their abilities to initiate radical and cationic photopolymerizations. J. Photochem. Photobiol. 174, 130-137 (2005).

15 Yoshioka, N., Andoh, C., Kubo, K., Igarashi, T. \& Sakurai, T. Competitive occurrence of homolytic $\mathrm{N}-\mathrm{O}$ and heterolytic $\mathrm{C}-\mathrm{O}$ bond cleavage in the excited-state 1-arylmethyloxy2-pyridones. J. Chem. Soc. 2, 1927-1932 (2001).

16 Gao, J., Li, N. \& Freindorf, M. Hybrid QM/MM simulations yield the ground and excited state $\mathrm{p} K_{\mathrm{a}}$ difference: phenol in aqueous solution. J. Am. Chem. Soc. 118, 4912-4913 (1996) and references cited therein.

17 Tanaka, K., Akimoto, R., Igarashi, T. \& Sakurai, T. Abilities of 2-arylmethyloxy-6cyanonaphthalene derivatives to initiate radical and cationic photopolymerizations. J. Polym. Sci. 44, 25-31 (2006).

18 Zimmerman, H. E. \& Sandel, V. R. Mechanistic organic photochemistry. II. Solvolytic photochemical reactions. J. Am. Chem. Soc. 85, 915-922 (1963).

19 Zimmerman, H. E. The meta effect in organic photochemistry: mechanistic and exploratory organic photochemistry. J. Am. Chem. Soc. 117, 8988-8991 (1995).

20 Zimmerman, H. E. Meta-ortho effect in organic photochemistry: mechanistic and exploratory organic photochemistry. J. Phys. Chem. 102, 5616-5621 (1998).

21 Pincock, J. A. Photochemistry of arylmethyl esters in nucleophilic solvents: radical pair and ion pair intermediates. Acc. Chem. Res. 30, 43-49 (1997).
22 Nevill, S. M. \& Pincock, J. A. The design of radical clocks to probe the reactivity of the intermediates in arylmethyl ester photochemistry. Can. J. 75, 232-247 (1997).

23 Cozens, F. L., Pincock, A. L., Pincock, J. A. \& Smith, R. The role of nonaromatic isomers in the photochemistry of 3,5-dimethoxybenzyl acetate. J. Org. Chem. 63, 434-435 (1998).

24 DeCosta, D. P., Bennett, A., Pincock, A. L., Pincock, J. A. \& Stefanova, R. Photochemistry of aryl tert-butyl ethers in methanol: the effect of substituents on an excited state cleavage reaction. J. Org. Chem. 65, 4162-4168 (2000).

25 DeCosta, D. P., Howell, N., Pincock, A. L., Pincock, J. A. \& Rifai, S. 1,3-Dimethoxy-5methylene-1,3-cyclohexadiene compounds with leaving groups at C6: generation, solvolytic reactivity, and their importance in the photochemistry of 3,5-dimethoxybenzyl derivatives. J. Org. Chem. 65, 4698-4705 (2000).

26 Sakurai, T., Kubo, K., Kojima, S., Shoro, T. \& Inoue, H. Photoinduced heterolysis of the carbon-oxygen bond in bichromophoric 1-arylmethyloxy-2-pyridones. Tetrahedron Lett. 39, 9747-9750 (1998).

27 Turro, N. J., Ramamurthy, V. \& Scaiano, J. C. 'Modern Molecular Photochemistry of Organic Molecules' 879-882 (University Science Books, California, 2010).

This work is licensed under the Creative Commons Attribution-NonCommercial-No Derivative Works 3.0 Unported License. To view a copy of this license, visit http:// creativecommons.org/licenses/by-nc-nd/3.0/ 